
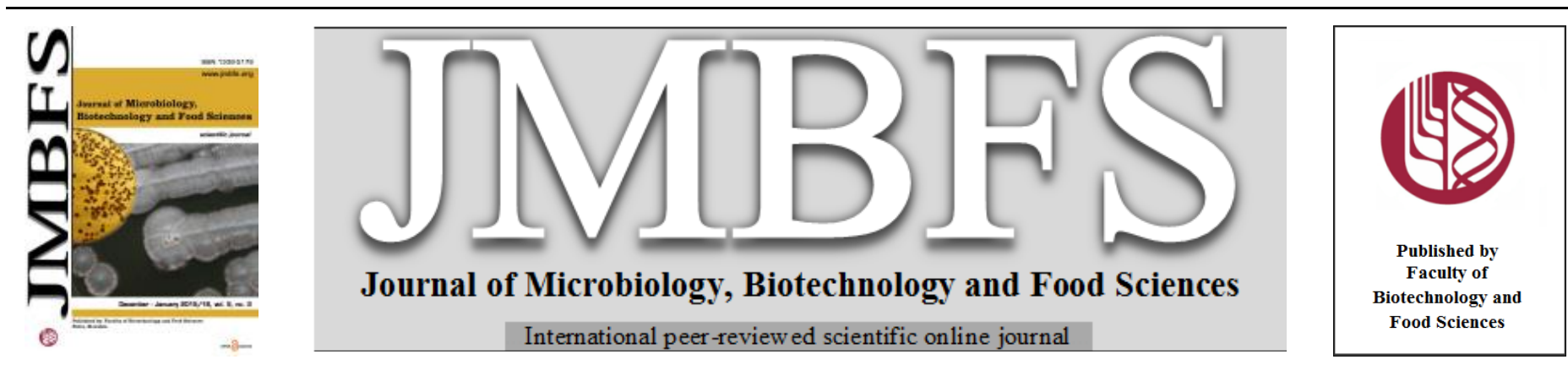

\title{
KRAFT LIGNIN DEGRADATION BY AUTOCHTONOUS STREPTOMYCES STRAINS ISOLATED FROM A TROPICAL LAGOON ECOSYSTEM
}

\author{
Olanike Maria Buraimoh ${ }^{* 1,2}$, Olukayode Oladipo Amund ${ }^{1}$, Matthew Olusoji Ilori ${ }^{1}$ \\ Address(es): Dr. Olanike Buraimoh, \\ ${ }^{1}$ University of Lagos, Faculty of Science, Department of Microbiology, Akoka, Yaba, Lagos State, Nigeria +234 8122640525. \\ 2 The Ohio State University, Department of Food, Agricultural and Biological Engineering, OH 44691, Wooster, Ohio, USA.
}

*Corresponding author: marianiks@yahoo.com

doi: $10.15414 / j m b f s .2015 / 16.5 .3 .248-253$

\section{ARTICLE INFO}

Received 2. 12. 2014

Revised 19. 8. 2015

Accepted 1. 10. 2015

Published 1. 12. 2015

Regular article

open ${ }_{\text {ACCESS }}$

\begin{abstract}
Kraft lignin contributes to the toxicity of the pulping plant effluent and is known to resist microbial treatment.The lignin component must be removed from lignocellulose biomass to enhance the release of fermentable sugars for the production of biofuel and other value-added end products. Lignin-degrading bacteria provide an advantage due to their ease of isolation,wider tolerance of environmental conditions and genetic manipulations compared with their fungal counterparts. There is no documented evidence on the degradation of kraft lignin by bacteria in the tropical estuarine ecological niche in Nigeria. Bacterial growth and assessment of kraftlignin degradation in submerged fermentation was carried out for a period of 10 days using Streptomyces spp isolated from a tropical lagoon as the inocula. The organisms utilized 23 to $99 \%$ kraft-lignin at the rate of $2.3 \times 10^{-5}$ to $9.9 \times 10^{-5} \mathrm{~g}^{-1} \mathrm{~d}^{-3}$ with specific growth rates of $0.020-0.084 \mathrm{~h}^{-1}$ and doubling times of $8.3-35.1 \mathrm{~h}$. Maximum values obtained for laccase and peroxidase activities were $9.5 \times 10$ ${ }^{2}$ and $400 \mu \mathrm{mol} \mathrm{mg}^{-1} \mathrm{~min}^{-1}$ respectively.

The aim of this study was to obtain evidences for Kraft lignin degradation by indigenous tropical estuarine Streptomyces species from Lagos, Nigeria.

The Autochthonous bacterial species of the Lagos lagoon utilize kraft lignin as a sole carbon source and may be good candidates for biotechnological purposes. The outcome of this study has bridged an information gap in the tropical environment and will complement existing global data because the information on the degradation of kraft lignin by marine Streptomyces is not common.
\end{abstract}

Keywords: Kraft lignin, Streptomyces, biodegradation, enzyme, lignocellulose, estuarine, lagoon

\section{INTRODUCTION}

The Lagos lagoon is a wide expanse estuarine waters located in the SouthWestern part of Nigeria, which is used for water transportation and as a repository for myriads of industrial and domestic wastes. Apart from pollution by hydrocarbons and sewage (Akpata and Ekundayo, 1978; Amund and Igiri, 1990), the lagoon is polluted by unquantifiable amounts of wood residues (sawdust) emanating from several sawmills fringing its shoreline (Akpata, 1986). The trans-boundary incursion of the water hyacinth (Eichornea crassipes) into the Lagos lagoon from the neighbouring creeks in Benin republic as well as plant litter from the mangrove forest also contribute significant amounts of lignocellulose to the lagoon.

Plant cell material is basically composed of cellulose, hemicellulose and lignin, the latter being the most difficult to biodegrade. Lignin is a polyphenolic structural constituent of wood and other plant materials that encrusts the cell wall and cement the cells together. It is a highly polymeric substance with a complex, cross-linked highly aromatic structure of molecular weight of about 10,000 D and derived from three phenyl propanoid units namely; coniferyl alcohol, coumaryl alcohol and sinapyl alcohol (Wong, 2008). Lignin is well known for resistance to microbial degradation because of its high molecular weight and presence of biologically-stable carbon-to-carbon ether linkages (Abd-Elsalam and ElHanafy, 2009). In addition, it represents an obstacle to microbial digestion of structural carbohydrates; both because it is a physical barrier and because of the depressing effect on microbial activity by the constituent phenolic compounds (Antongiovann and Sargentini, 1991; Chandra et al., 2012). Kraft lignin (KL) is similar to natural lignin, and has been widely used for lignin-related studies. It is also the major by-product in the relatively high alkaline effluent (black liquor) generated by the pulp and paper industry (Yan, 2013).

Physical and chemical treatment methods or a combination of both exists for the breakdown of lignocellulosic compounds; however, these methods are costly and hazardous to the environment (El- Hanafy et al., 2008; Chandra et al., 2012). Currently, much attention is drawn to the biological methods because it appears to be a promising alternative due to their environmental friendliness. Despite its apparent resistance to degradation, microorganisms including fungi, bacteria and actinomycetes abound, which oxidatively degrade lignins (Tien and Kirk, 1983; Hernandez et al., 2001; El- Hanafy et al., 2008; Chandra et al., 2012). However, lignin degradation by microorganisms is well studied in the domain of aerobic fungi (Dehorter and Blondeau, 1992; Achi, 1994). Among them, the white rot fungi have received extensive attention due to the presence of efficient extracellular ligninolytic enzyme activities (Churphal et al., 2005). Practically, fungi are not stable under extreme environmental conditions such as high temperature and $\mathrm{pH}$, extractives and lignin concentration. They are also difficult to cultivate in submersed condition and oxygen limitations. However, Lignindegrading bacteria provide an advantage and have been reported to play a significant role in the decomposition of lignin due to their ease of isolation,wider tolerance of environmental conditions and genetic manipulations compared with their fungal counterparts.(Chandra et al., 2007, 2008; Masai et al., 2007; ElHanafy, 2008.

One of the best characterized lignin-degrading bacteria (Sphingomonas paucimobilis SYK-6) capable of growth on a wide variety of lignin-related compounds was reported by Masai et al. (2007). Chandra et al., 2007, 2008 investigated a good number of lignin-degrading bacteria belonging to the genera Serratia, Citrobacter, Klebsiella, Paenibacillus, Aneurinibacillus and Bacillus; some of them were positive in the treatment of black liquor (Raj et al., 2007) Also, two soil aromatic degrading-bacteria (Pseudomonas putida and Rhodococcus sp. RHA1), were found to possess lignin-degrading activity during two novel spectrophotometric assays for lignin breakdown (Ahmad et al., 2010). The role of fungi in the degradation of cellulose arising from sawdust pollution of the Lagos lagoon had received some research consideration (Akpata,1986). The role of estuarine bacterial species in this ecosystem for the degradation of lignin and cellulose components of sawdust was reported by Buraimoh et al.,2015a, whereas, there is no documented evidence on the degradation of kraft lignin by bacteria in this estuarine ecological niche in South-West Nigeria. Kraft lignin $(\mathrm{KL})$ is the main contributor to the colour and toxicity of the pulping plant effluent and is known to resist microbial treatment because it has undergone alkaline sulphite treatment. Also, the lignin component has to be removed to enhance the release of fermentable sugars from lignocelluloses to achieve the production of biofuel and other value-added products (Chen and Dixon, 2007). 
The discovery of novel marine lignin-degrading bacteria or their enzymes provide an advantage due to their ease of isolation, ability to survive extreem environmental conditions and amenability to genetic manipulation.

The aim of our study was to obtain evidences for Kraft lignin degradation by indigenous tropical estuarine Streptomyces species of the Lagos lagoon, Nigeria, for future biotechnological application. It was also set to bridge a global information gap because the information on the degradation of kraft lignin by marine Streptomyces is not common.

\section{MATERIAL AND METHODS}

\section{Microorganisms}

The Streptomyces strains used in this study were isolated from a tropica estuarine ecosystem in Lagos, Nigeria. Isolation, screening and identification of strains for ligninolytic activity have been previously described in detai (Buraimoh et al., 2015b). Five Streptomyces strains that showed the capability to break down lignin were selected and used for this study. They were identified previously on the basis of morphological and biochemical characteristics, electron microscopy and 16S rRNA gene sequencing as: Streptomyces albogriseolus strain AOB KF977548, Streptomyces aureus strain BOB KF977549, Streptomyces coelicolor strain COB KF977550, Streptomyces albus strain DOB KF977551 and Streptomyces pseudogriseolus strain EOB KF97752. Phylogenetic analysis of the strains compared with other strains in the GenBank were analysed using Mega 6 software as previously described (Buraimoh, $\boldsymbol{e t}$ al. 2015a).

\section{Bacterial Growth Studies on Kraft Lignin}

A mineral salts medium $(100 \mathrm{ml})$ in deionized water contained (gram per liter) $\mathrm{KH}_{2} \mathrm{PO}_{4}, 2.0 ; \mathrm{K}_{2} \mathrm{HPO}_{4}, 2.0 ; \mathrm{MgSO}_{4} .7 \mathrm{H}_{2} \mathrm{O}, 0.05$, yeast extract $0.1 \mathrm{~g}, \mathrm{MnCl} .7 \mathrm{H}_{2} \mathrm{O}$

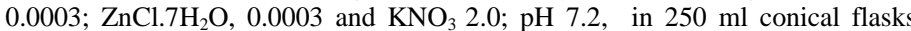
supplemented with $0.1 \%$ kraft lignin (Indulin AT, Mead Westvaco, Glen Allen, VA,USA) as sole carbon source was autoclaved $\left(121^{\circ} \mathrm{C}, 15 \mathrm{~min}\right)$ and inoculated with $1.0 \mathrm{ml}$ of pure cultures (inocula). Incubation was done on a rotary shaker $\left(30^{\circ} \mathrm{C}, 150 \mathrm{rpm}\right)$ for 10 days. Batch harvesting was done at intervals (48 h) and the content filtered using a pre-weighed sterile filter paper (Whatman No. 42). Growth of organisms was monitored by the dry weight method as described earlier (Ball et al., 1989). This is because Streptomyces species grow in mycelia chains or pellets; hence the turbidity method would not be suitable. The filtrates were used for the evaluation of kraft-lignin degradation.

\section{Analysis of Growth Kinetics}

Mean generation times $\left(\mathrm{T}_{\mathrm{d}}\right)$ and the specific growth rate $\left(\mathrm{h}^{-1}\right)$ of the isolates on kraft lignin were calculated using non-linear regression of growth curves using prism version (Graph pad software, San Diego, CA).

\section{Assessment of kraft Lignin Degradation in Culture Broth}

Lignin degradation was monitored as previously described (Abd-Elsalam and El-Hanafy, 2009). Culture broth $(1.0 \mathrm{ml})$ was centrifuged $(10,000 \times \mathrm{g}, 5 \mathrm{~min})$ The clear supernatant $(250 \mu \mathrm{l})$ was diluted by adding phosphate buffer $(2.5 \mathrm{ml}$, $\mathrm{pH}$ 7.5). Lignin content was measured at $280 \mathrm{~nm}$ using a UV-visible spectrophotometer (Beckman Coulter, DUR 800, Beckman Coulter Inc. Fullerton, CA). Graded concentrations of kraft lignin were obtained through dilution in series. Preparation of standard curve was done by preparing stock solution $\left(1.0 \mathrm{~g} \mathrm{l}^{-1}\right)$ of kraft lignin using phosphate buffer $(2.5 \mathrm{ml}, \mathrm{pH} 7.5)$ as a diluent. Further dilutions were made as appropriate . A straight line curve with a correlation of 0.998 was obtained. Lignin values were extrapolated from the standard curve. The $\mathrm{pH}$ of the supernatant was determined at intervals $(48 \mathrm{~h})$ using the ADWA professional IP67 water proof $\mathrm{pH}$ pocket tester (ADWA Instruments, Alsokikoto, Szeged, Hungary).

\section{Laccase Assay}

Culture filtrates obtained at intervals $(24 \mathrm{~h})$ from each of the culture flasks were centrifuged $\left(10,000 \times \mathrm{g}, 4{ }^{\circ} \mathrm{C}, 10 \mathrm{~min}\right)$. The supernatants were used as the source of enzymes. Laccase activity was measured as described earlier (Kizhekkedathu et al., 2007) by monitoring the oxidation of 2,2 - azino-bis-[3-ethy] benzothiazoine-6-sulfonic acid] (ABTS) $(500 \mu \mathrm{mol})$ using a UV-visible spectrophotometer (Beckman coulter, DUR 800, Beckman coulter Inc. Fullerton, CA).) at $420 \mathrm{~nm}$ for $1 \mathrm{~min}$. The reaction mixture $(3 \mathrm{ml})$ contained: culture supernatant $(1.0 \mathrm{ml})$, ABTS $(1.0 \mathrm{ml})$ and $1.0 \mathrm{ml}$ phosphate buffer $(0.2 \mathrm{M}, \mathrm{pH} 7.5)$ One unit of enzyme activity was defined as $1 \mathrm{mM}$ of ABTS oxidized per min. (The extinction coefficient $=3.6 \times 10^{4} \mathrm{~mol}^{-1} \mathrm{~cm}^{-1}$ ).

\section{Lignin Peroxidase Assay}

Extracellular lignin peroxidase (Lip) activity was assayed as described earlier (Kizhekkedathu and Parukuttyyamma, 2005) using 2,4-dichlorophenol (2,4-
DCP,SIGMA -ALDRICH Co.,St.Lois, MO,USA) as the substrate. The reaction mixture $(1.0 \mathrm{ml})$ contained $200 \mu \mathrm{l}$ each of potassium phosphate buffer $(0.1 \mathrm{M}$ $\mathrm{pH}$ 7.0), $25 \mathrm{~m}$ mol 2,4-DCP, $16 \mathrm{~m}$ mol 4-amino antipyrine and culture filtrate The reaction was initiated by the addition of $200 \mu \mathrm{l}$ of $50 \mathrm{~m}$ mol hydrogen peroxide $\left(\mathrm{H}_{2} \mathrm{O}_{2}\right)$ and was monitored for $1 \mathrm{~min}$ at a wave length of $510 \mathrm{~nm}$ using a spectrophotometer (Beckman coulter, DUR 800, Beckman coulter Inc. Fullerton, CA). An absorption coefficient of $21.647 \mathrm{M}^{-1} \mathrm{~cm}^{-1}$ was used for the calculation of enzyme activity.

\section{Protein Determination}

Protein content of crude extract was determined as described previously (Frolund et al., 1996). Solution A for Protein assays contained: sodium carbonate $(20 \mathrm{~g})$, sodium hydroxide $(4 \mathrm{~g})$ potassium sodium tartarate $(0.2 \mathrm{~g})$ dissolved in $1000 \mathrm{ml}$ of distilled water. Solution B $(100 \mathrm{ml})$ contained: copper sulphate $(0.5 \mathrm{~g})$. Solutions A and B were kept in the refrigerator $\left(4{ }^{\circ} \mathrm{C}\right)$. Solutions $\mathrm{A}$ and $\mathrm{B}$ were mixed in a ratio of 50:1, Just prior to use. Lowry and FolinCiocalteau phenol reagent (Sigma Aldrich) was diluted by adding $5 \mathrm{ml}$ of $2 \mathrm{~N}$ Folin- Ciocalteau's reagent to $6 \mathrm{ml}$ of distilled water. Bovine serum albumin (BSA,0.05g) was dissolved in a volumetric flask using distilled water $(500 \mathrm{ml})$, It was stirred thoroughly to dissolve ( final concentration of $100 \mathrm{mg} \mathrm{BSA} / \mathrm{L}$ stock) and prepared fresh $1 \mathrm{~h}$ before the onset of the experiment. From this stock, graded concentrations of BSA were used as standards. Standard curve with a regression coefficient of 0.997 was obtained.

\section{RESULTS}

\section{Kinetics of Kraft-Lignin Biodegradation}

Growth patterns of organisms are shown in Fig.1. They exhibited exponential growth patterns in the first 2 days. The highest biomass $\left(4.2 \mathrm{mg} \mathrm{L}^{-1}\right)$ was exhibited by strain COD. The Streptomyces strains displayed varied capabilities to degrade kraft lignin (23-99\%) within 10 days of exposure. Results are shown in figure 2.

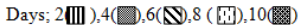

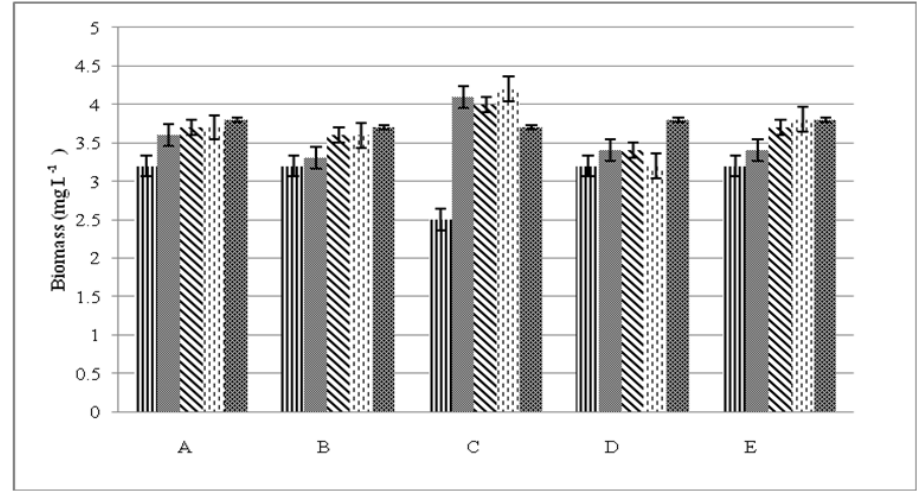

Figure 1 Biomass production by Streptomyces species growing on kraft lignin. A - Streptomyces albogriseolus strain AOB, B - Streptomyces aureus strain BOB, C - Streptomyces coelicolor strain COB, D - Streptomyces albus strain DOB, E - Streptomyces pseudogriseolus strain EOB.

Uninoculated medium was used as control in all cases. All experiments were carried out in triplicates. The values were presented as mean values. SD: AOB0.023, BOB- 0.022, COB- 0.070, DOB- 0.024, EOB- 0.027.
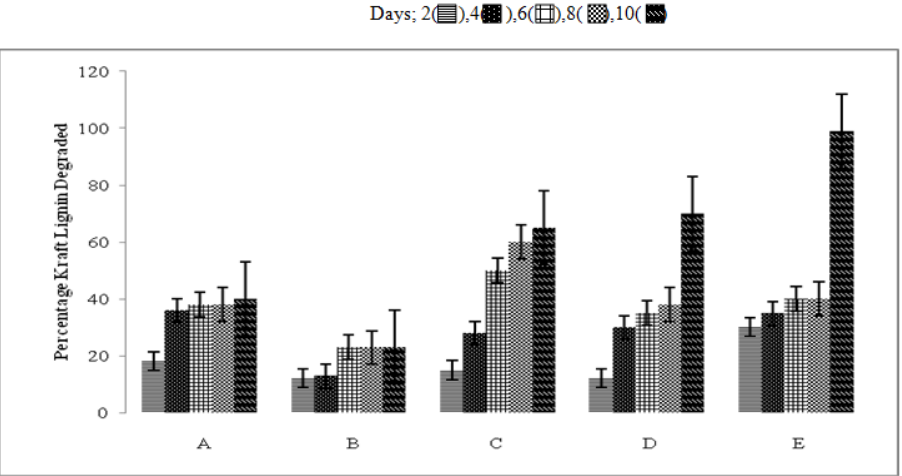

Figure 2 Kraft lignin removal in growth cultures of Streptomyces species.

A - Streptomyces albogriseolus strain AOB, B-Streptomyces aureus strain BOB, C - Streptomyces coelicolor strain COB, D - Streptomyces albus strain DOB, E Streptomyces pseudogriseolus strain $\mathrm{EOB}$

SD: AOB- 9.0, BOB- 5.8, COB- 21.4, DOB- 21.0, EOB- 28.4 
Spectrophotometric analysis of Kraft lignin degradation showed that at the end of the cultivation period, the maximum kraft lignin utilized was exhibited by Streptomyces pseudogriseolus strain EOB at the rate of $9.9 \times 10^{-5} \mathrm{~g} . \mathrm{d}^{-1} \mathrm{~cm}^{-3}$ with a specific growth rate of $0.084 \mathrm{~h}^{-1}$ and a doubling time of $8.3 \mathrm{~h}$. In the uninoculated control flask, no apparent decrease of the Kraft lignin content was observed, affirming that depletion of the substrate from the MSM was due to biodegradation by the strains and not due to abiotic losses (Table1).

Table 1 Growth kinetics' data for utilization of kraft lignin in liquid cultures by Streptomyces species

\begin{tabular}{lcccc}
\hline Strains & $\begin{array}{c}\text { Kraft lignin } \\
\text { degraded } \\
(\%)\end{array}$ & $\begin{array}{c}\text { Rate of } \\
\text { degradation } \\
\left(\mathbf{g ~ d ~}^{-1} \mathbf{c m}^{-3}\right)\end{array}$ & $\begin{array}{c}\text { Specific } \\
\text { growth } \\
\text { rate } \\
\left(\mathbf{h}^{-\mathbf{1}}\right)\end{array}$ & $\begin{array}{c}\text { Doubling } \\
\text { time (h) }\end{array}$ \\
\hline $\begin{array}{l}\text { Streptomyces } \\
\text { albogriseolus } \\
\text { strain AOB }\end{array}$ & 40 & $4.0 \times 10^{-5}$ & 0.029 & 23.5 \\
$\begin{array}{l}\text { Streptomyces } \\
\text { aureus } \text { strain }\end{array}$ & 23 & $2.3 \times 10^{-5}$ & 0.020 & 35.1 \\
$\begin{array}{l}\text { BOB } \\
\text { Streptomyces } \\
\text { coelicolor } \\
\text { strain COB }\end{array}$ & 65 & $6.5 \times 10^{-5}$ & 0.059 & 11.7 \\
$\begin{array}{l}\text { Streptomyces } \\
\text { albus } \text { strain }\end{array}$ & 70 & $7.0 \times 10^{-5}$ & 0.019 & 37.3 \\
$\begin{array}{l}\text { DOB } \\
\begin{array}{l}\text { Streptomyces } \\
\text { pseudogriseol }\end{array}\end{array}$ & 99 & & & \\
us strain EOB & & $9.9 \times 10^{-5}$ & 0.084 & 8.3 \\
\hline
\end{tabular}

\section{Laccase Activities}

The time course of laccase production showed that the maximum laccase activity produced by Streptomyces albogriseolus strain AOB occurred by day two $\left(9.5 \times 10^{-2} \mu \mathrm{mol} \mathrm{ml}{ }^{-1} \mathrm{~min}^{-1}\right)$ after which a gradual reduction was observed. On the other hand, the maximum laccase activity of Streptomyces coelicolor strain $\mathrm{COB}$ $\left(6.3 \times 10^{-2} \mu \mathrm{mol} \mathrm{ml}^{-1} \mathrm{~min}^{-1}\right)$ was observed by day 10 . Results are shown in Fig.3

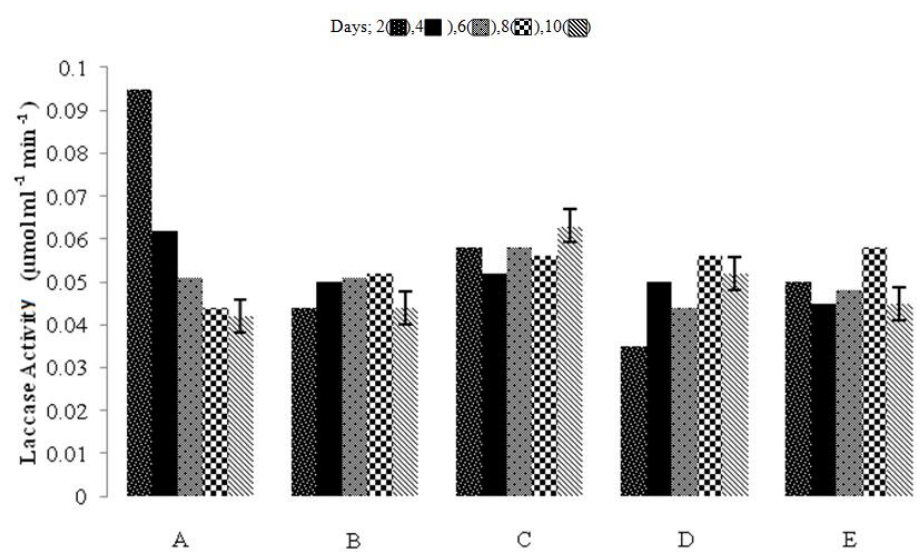

Figure 3 Laccase activities of Streptomyces species in growth cultures.

A -Streptomyces albogriseolus strain AOB, B - Streptomyces aureus strain BOB, C - Streptomyces coelicolor strain COB, D - Streptomyces albus strain DOB, E Streptomyces pseudogriseolus strain EOB.

Uninoculated medium was used as control in all cases. All experiments were carried out in triplicates. The values were presented as mean values. SD: AOB0.22, BOB- 0.04 , COB- 0.04 , DOB- 0.08, EOB- 0.05

\section{Peroxidase Activities}

Streptomyces albus strain DOB produced the highest extracellular lignin peroxidase activity $\left(400 \mu \mathrm{mol} \mathrm{ml}^{-1} \mathrm{~min}^{-1}\right)$ within $48 \mathrm{~h}$, Strain AOB showed the lowest activity of $90 \mu \mathrm{mol} \mathrm{ml}{ }^{-1} \mathrm{~min}^{-1}$ (Fig.4).

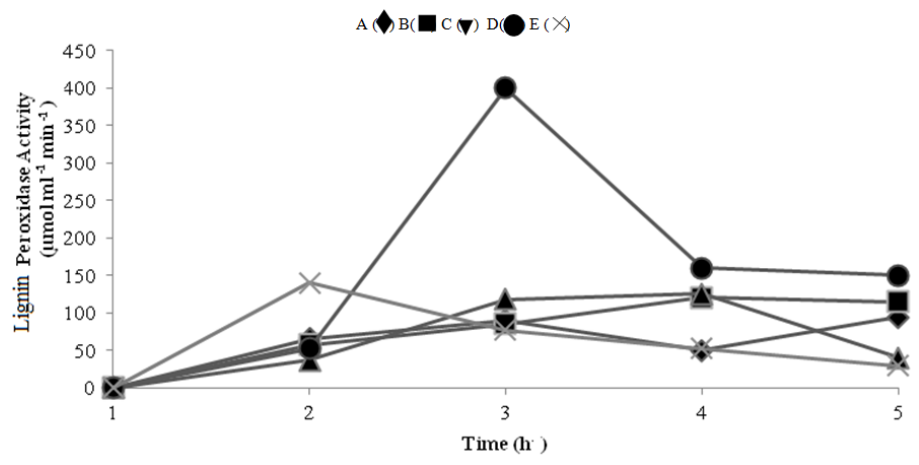

Figure 4 Extracellular lignin peroxidase activities of Streptomyces species in growth cultures.

A - Streptomyces albogriseolus strain AOB, B - Streptomyces aureus strain BOB C - Streptomyces coelicolor strain COB, D - Streptomyces albus strain DOB, EStreptomyces pseudogriseolus strain EOB

\section{Protein Analysis}

At the end of the incubation period, the total protein produced by strain AOB was $0.75 \mathrm{Mg} \mathrm{L}^{-1}$ by day 2 , and thereafter accumulated up to $0.90 \mathrm{Mg} \mathrm{L}^{-1}$ of protein. The quantity of protein released by strains BOB, COB, DOB and EOB (Fig.5) fluctuated between $0.6-1.10 \mathrm{Mg} \mathrm{L}^{-1}$ throughout the incubation period The highest quantity of protein was synthesized in the culture by strain $\mathrm{COB}$ $\left(1.10 \mathrm{Mg} \mathrm{L}^{-1}\right)$ by day 4 , while the lowest quantity was synthesized by strain DOB by day 8 .
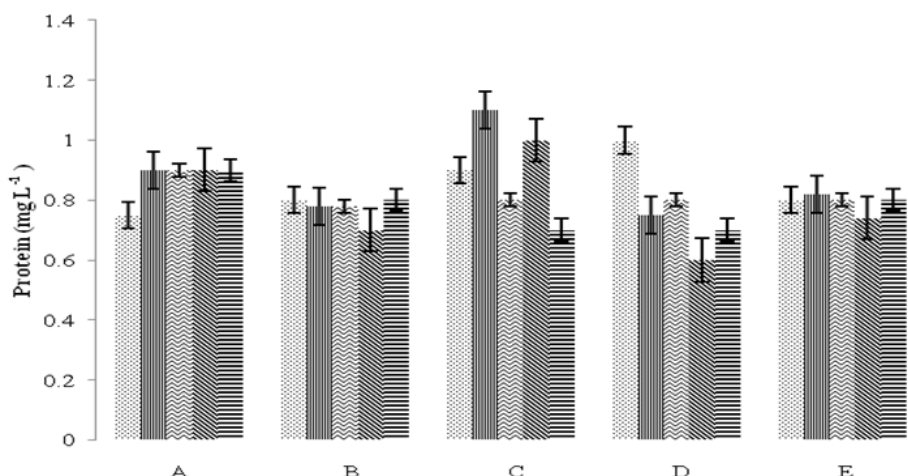

E

Figure 5 Extracellular protein release by Streptomyces species in growth cultures.

A - Streptomyces albogriseolus strain AOB, B - Streptomyces aureus strain BOB C - Streptomyces coelicolor strain COB, D - Streptomyces albus strain DOB, E Streptomyces pseudogriseolus strain EOB.

Uninoculated medium was used as control in all cases. All experiments were carried out in triplicates. The values were presented as mean values. SD: AOB0.068 , BOB- 0.034 , COB- 0.160 , DOB- 0.150 , EOB- 0.030

\section{pH change}

Continuous $\mathrm{pH}$ monitoring revealed that there was a drop in $\mathrm{pH}$ of the medium from 7.2 to 6.6 in the experimental flasks inoculated with strains AOB and DOB by day 2 , but by day 5 , the $\mathrm{pH}$ of the medium increased to 7.9 before dropping again to between $7.0-7.3$ by day 6 . The $\mathrm{pH}$ of the medium containing strain EOB was 7.0 by day 2, but by day 5 , it was 7.9 and by the 10 th day it was 7.1 , whilst the $\mathrm{pH}$ elicited by strains $\mathrm{BOB}$ and $\mathrm{COB}$ was between 7.2 and 7.5 throughout the incubation period. The greatest $\mathrm{pH}$ decrease elicited by most of the isolates occurred by day 2 (Supplementary Figs. 1 a-e).

\section{DISCUSSION}

Varying degradation rates and growth patterns were displayed by the Streptomyces species in this study. With respect to strain AOB, the growth and degradation pattern appeared to be exponential and rapid in the first 4 days, after which the percentage degradation and growth became slow but gradual till the termination of the experiment (supplementary Figs. 1 a-e).The degradation of kraft lignin by strain $\mathrm{COB}$ was gradual throughout the experimental period. Although there was a gradual build up of biomass by this isolate untill day 4 , a fluctuation in biomass was observed between day 4 and 8 after which a decline was observed till the termination of the experiment. Diauxic-type degradation curves were observed with strains BOB, DOB and EOB. The percentage kraft lignin degraded in strain BOB appeared to be exponential up to day 2 (12\% 
with a biomass of $3.2 \mathrm{Mg} \mathrm{L}^{-1}$ ), followed by a lag between day 2 and 4 . There after, there appeaered to be a rapid degradation till day $6(23 \%$, biomass of 3.8 $\mathrm{Mg} \mathrm{L}^{-1}$ ). The organism then appeared to have stopped the utilization of the substrate untill the experiment was terminated by day 10 . For strain DOB, there was a gradual degradation of kraft lignin up to $40 \%$ by the 8 th day followed by a sharp and rapid degradation (up to 70\%) till the termination of the experiment This strain displayed no visible lag growth phase, hence the growth phase appeared to be exponential till day 2 with a biomass of $3.2 \mathrm{Mg} \mathrm{L}^{-1}$. After then, the growth appeared to be stationary until a drop in biomass $\left(3.0 \mathrm{Mg} \mathrm{L}^{-1}\right)$ was observed by day 8 . This was followed by an exponential growth till the experiment was terminated on the 10th day with a total biomass of $3.8 \mathrm{Mg} \mathrm{L}^{-1}$. Strain EOB utilized kraft lignin rapidly the first 2 days (25\%) to build a biomass of 3. $2 \mathrm{Mg} \mathrm{L}^{-1}$. A lag phase was observed between day 2 and 4 after which there was a slight increase in biomass (up to $3.8 \mathrm{MgL}^{-1}$ ) between day 4 and 6 . After then,the growth appeaered stationary till the experiment was terminated. Different authors have expressed their opinions with respect to lignin degradation, some of which are similar to the findings made in this study. Crawford and Crawford (1980) were of the opinion that even though kraft lignins appeared more resistant to microbial attack than natural lignins, kraft lignins were decomposed more rapidly during the first 100 - $200 \mathrm{~h}$ (4-8 days) depending on lignin type, after which there is reduced rates of degradation upon prolonged incubation. Marton, (1971), suggested that the reduced rate of kraft lignin degradation upon prolonged incubation might be due to the considerable chemical alteration (including sulfonation and condensation reactions) from their natural state during pulping. However, El-Hanafy et al. (2008) reported 76.3 and $67 \%$ values for lignin alkali degradation by Bacillus spp BahHAE3 and BahHAE8 respectively. This, they attributed to a long adaptation period of 40 days. The authors pointed out that individual samples varied greatly in their overall rates of degradation and that lower molecular weight fractions of the kraft-lignin were decomposed at a significantly faster rate. This, according to the authors, is probably because kraft lignin had been fragmented considerably during pulping. In their study on the long-term stability of various waste lignins in a model aquatic ecosystem, Bouveng and Solyom (1973) found that all the lignins examined contained two fractions, one that was readily biodegradable in aquatic systems and a second which was more resistant to biodegradation Buraimoh et al. 2015b studied the in situ and laboratory degradation of natura lignin component of wood residues by lignocellulolytic bacteria over an incubation period of 6 Months. In their findings, the authors reported $22.49 \%$ $52.49 \%$ degradation (laboratory study) and $52.33-82.52 \%$ under in situ condition. The authors attributed several factors to the higher degradation rates under in situ conditions compared to the laboratory experiment. In this study however, it is worthy of note that Streptomyces pseudogriseolus strain EOB, Streptomyces albus strain DOB and Streptomyces coelicolor strain COB effectively degraded 99,70 and $65 \%$ kraft lignin respectively within 10 days of incubation in submerged systems. This is similar to the findings of Hassan and Amr (2009). They identified two Bacillus spp from Egyptian soil which degraded synthetic lignin (alkali lignin) as a sole carbon source and achieved a maximum degradation $(81.4 \%)$ on the sixth day. Also, Deschamps et al. (1980) found that Aeromonas sp had degraded $98 \%$ of kraft lignin (indulin AT, $1 \mathrm{~g} \mathrm{~L}^{-1}$ ) as the sole carbon source after five days of incubation. The low rate of degradation observed with Streptomyces aureus strain BOB is similar to the findings of Chandra et al. (2007). Even though the authors used glucose (1\%) as additional carbon source for lignolytic bacteria; Paenibacillus sp, Aneurinibacillus aneurinilyticus and Bacillus sp were reported to have degraded 37,33 and $30 \%$ kraft lignin $\left(0.7 \mathrm{~g} \mathrm{~L}^{-1}\right)$ respectively. Also, Monties, et al.(1981), isolated 11 Gram negative aerobic soil bacteria and found that poplar dioxane lignin and milled wood lignin degradation rates ranged between $20-40 \%$ of initial content after 7 days.

Perestelo et al. (1989) suggested that the inhibitory effect of low molecular lignin fragments may be responsible for the decline in the culture growth rate usually observed during the 5th and 6th day of incubation with kraft lignin. In their report, S. marcescens grown in the presence of $0.1 \%$ kraft lignin as sole carbon source declined until totally killed after 4 days of incubation. The authors however reported that this inhibitory effect was not present when the medium was supplemented with glucose. However, Buraimoh et al. (2015b) are of the opinion that apart from factors such as $\mathrm{pH}$ and temperature; nutrient and oxygen depletion and accumulation of toxic products of degradation may be implicated in the amount of lignin degraded in the culture flask.

The growth curve indicated that strain AOB may likely be in its stationary phase of growth and if the incubation period was extended it could probably enter into another exponential phase of growth or their growth may probably decline. The rate of substrate degradation was gradual and corresponded with biomass formation by strain $\mathrm{COB}$. Though the growth curve indicated that the biomass of this organism started to decline by day 10 , however, decrease in lignin degradation rate was not evident as at day 10 (supplementary Fig. 1c).This phenomenon observed with strain $\mathrm{COB}$ may not necessarily be the same for others. For example, the biomass produced by Streptomyces albogriseolus AOB was $3.8 \mathrm{mg} \mathrm{L}^{-1}$ by day 10 and it degraded $40 \%$ of the substrate whereas Streptomyces aureus BOB also had a biomass of $3.8 \mathrm{mg} \mathrm{L}^{-1}$ but degraded only 23 $\%$ of the subtrate at the end of the incubation period. Likewise, the same biomass
(3.8 $\mathrm{mg} \mathrm{L}^{-1}$ ) was recorded for Streptomyces pseudogriseolus strain EOB and Streptomyces albus strain DOB that degraded 99 and $70 \%$ of subsrates respectively. Streptomyces coelicolor strain $\mathrm{COB}$ which degraded $65 \%$ of the kraft-lignin had a biomass of up to $4.2 \mathrm{mg} \mathrm{L}^{-1}$ at the end of the incubation period. It could be deduced that the rate of enzyme production (which is responsible for substrate degradation ) of each strain differ and may not be dependent on the growth phase. It is noteworthy also that the specific growth rate and doubling time of the organisms differ, and may be a contributing factor as observed with strain EOB which showed the highest percentage lignin degradation (99\%) with the highest specific growth rate but the shortest doubling time.

According to Kirby, (2005), the two major groups of enzymes involved in lignin degradation are peroxidases and laccases. The Streptomyces strains studied exhibited enzymatic degradation of lignin by oxidizing the lignin polymer. This is evidenced by laccase activities as herein reported. There was a variation in the time and degree of maximum laccase activities in the culture filtrate. It was also observed that enzyme activities does not correlate with biomass formation. This may be due to the migration rate and molecular weight of the enzymes produced by different strains, the culture conditions and length of incubation. This is in line with the findings of Sridev and Singaracharya (2011). During their study on isolation, identification and screening of potential cellulase-free xylanaseproducing fungi, they found that enzyme activities did not correlate with biomass formation and were of the opinion that this may due to migration, molecular weight and temperature. Morii et al.(1995) however, are of a contrary opinion, They isolated Bacillus megaterium, Azotobacter and Serratia marcescens from compost soil capable of decolourizing or solubilizing lignin. S. marscens produced laccase which activity correlated positively with lignin mineralization and solubilization. Chandra et al. (2011) studied the degradation and detoxification of pulp paper mill effluent (PPME) by mixed bacterial strains (Serratia marcescens, S. liquefaciens and $B$. cereus) in different ratio. They found that ratios 4:1:1 and 1:4:1 were effective for the degradation of PPME, this, they attributed to the production of more enzyme for ratio 4:1:1 during degradation. The authors reported that the presence of enzyme in the medium depends on the constituents of the culture medium, availability of substrate and potentiality of organisms to secrete a particular enzyme. They however noted that degradation of the compound and induction of the enzyme is a simultananeous process which support each other. The effect of length of incubation and temperature on enzyme activity was reported by Tomati et al. (1995). They observed $70 \%$ of lignin degradation during 35 days of incubation when the temperature of compost was kept at $50{ }^{\circ} \mathrm{C}$ but during the later maturing phase, lignin was again degraded with the ratio increasing to $24.84 \%$ by day 45 . Kizhekkedathu and Parukuttyyamma, (2005) found out that six isolates (actinomycetes) from the marine mangrove areas produced lignin peroxidase out of which four of them also showed laccase activities. This is in agreement with this study.The Streptomyces strains showed peroxidase and laccase activities of up to $400 \mu \mathrm{mol} \mathrm{ml}^{-1} \mathrm{~min}^{-1}$.

$\mathrm{pH}$ is an important parameter for laccases as their activities are $\mathrm{pH}$ dependent (Machczynski et al. 2004). Hassan and Amr (2009) reported that the maximum lignin degradation occurred at $\mathrm{pH}$ 6. Also, El-Hanafy et al. (2008) earlier reported that Bacillus strains BahHAE3 and BahHAE8 reached maximum lignin degradation at $\mathrm{pH} 6$ (76.3 and $67.1 \%$ degradation respectively), the minimum lignin degradation at $\mathrm{pH} 12$ for BahHAE3 (EU344808) and $\mathrm{pH} 13$ for BahHAE8. They however reported that BahHAE8 (EU844809) kept higher lignin degradation range at $\mathrm{pH} 8$ to 11 than strain BahHAE3. The $\mathrm{pH}$ of the growth medium in this study remained between 6.6 and 8.0 throughout the incubation period and has no significant impact on the culture growth. This is similar to the report of Raj et al. (2007). In their study on the biodegradation of kraft-lignin by Bacillus sp (AY952465) isolated from the sludge of a pulp and paper mill, the authors found that an increase in the $\mathrm{pH}$ during the growth of the strain till it reached an alkaline $\mathrm{pH}$, did not alter the culture growth significantly. Pometto III and Crawford (1986) studied the effects of $\mathrm{pH}$ on lignin and cellulose degradation by Streptomyces viridosporus and reported that mineralization of lignin and cellulose to $\mathrm{CO}_{2}$ was optimal at $\mathrm{pH} 6.5-7.0$ respectively, but that the optimum $\mathrm{pH}$ for lignin and cellulose solubilisation was 8.5. The slight fluctuation in $\mathrm{pH}$ observed in this study may be as a result of the release of some low molecular weight lignin fragments into the medium. within the period of incubation.

The results showed that the quantity of total protein synthesized by the isolates did not linearly correspond with enzyme activity. For example, when the concentration of protein was measured against laccase activity, Streptomyces albogriseolus strain $\mathrm{AOB}$ had its lowest quantity of protein $\left(0.75 \mathrm{mg} \mathrm{mL}^{-1}\right)$ on day 2 and coincidentally, laccase activity was highest on the same day. Subsequently, laccase activity decreased gradually. A similar observation was made for Streptomyces albus strain DOB, where the lowest amount of protein was produced by day $8\left(0.65 \mathrm{mg} \mathrm{mL}^{-1}\right)$ and the highest laccase activity occurred on the same day. The same picture was also presented by strain EOB. However, different observation was made with Streptomyces coelicolor strain COB. The highest protein was synthesized by day 4 , with highest laccase activity of $6.3 \times 10$ $\mu \mathrm{mol} \mathrm{mg}{ }^{-1} \mathrm{~min}^{-1}$, occurring by day 10 . This may not be unusual and is similar to the findings of Frolund et al. (1996). Different proteins synthesized by the strains may be accumulated in the medium apart from peroxidases and laccases. 
Also,the relevant proteins may lose their activity with time, Moreover, different organisms also produce different proteins with varied optimum temperatures and $\mathrm{pH}$ which may have effects on their activities.

\section{CONCLUSION}

The autochthonous bacterial species of the Lagos lagoon utilized kraft lignin considerably as a sole carbon source. Marine bacteria are known to produce enzymes of high biotechnological value. They could play a major role in the biorehabilitation of the lignin-polluted water of the lagoon, thereby solving an ecological problem. They could be enhanced for biotechnological purposes for the production of value-added products such as ethanol from lignocellulosic wastes. This work has bridged an information gap in the tropical environmen and will complement existing global data. Factors such as variation of growth conditions, lignin structure, concentration of substrate, the bacterial strain and their ability to synthesize the required enzyme may be implicated in the variation of lignin degradation rate, and as such further work would be carried out on the optimization and characterization of the enzymes produced from each of the organisms. In addition to this, the detection of gene mediating enzyme production in the genome of the respective strains would be examined.

Acknowledgments: Special thanks to Dr. Fred Michel of Ohio Agricultura Research Development Centre, (OARDC) Wooster, Ohio, USA where the enzyme assays were carried out.

\section{REFERENCES}

ABD-ELSALAM, H.E., EL-HANAFY, A.A. 2009. Lignin biodegradation with lignolytic bacterial strain and comparism of Bacillus subtilis and Bacillus sp isolated from Egyptian soil. American-Eurasian Journal of Agriculture and Environmental Sciences, 5(1), 39-44

AHMAD, M., TAYLOR, C.R., PINK, D., BURTON, K., EASTWOOD, D. BENDING, G.D., BUGG, T.D.H. 2010. Development of novel assays for lignin degradation: Comparative Analysis of bacterial and fungal lignin degraders Molecular Biosystems, 6, 815-821.b http://dx.doi.org/10.1039/b908966g

ACHI, O. K. 1994. Growth and coal-solubilising activity of Penicillium simplicissimum on coal related aromatic compounds. Bioresource Technology, 48 (1), 53-57. http://dx.doi.org/10.1016/0960-8524(94)90136-8

AKPATA, T. V.I. 1986. Effect of sawdust pollution on the germination of fungal spores in Lagos lagoon. Environmental Pollution, 44(1),37- 48 http://dx.doi.org/10.1016/0269-7491(87)90127-8

AKPATA, T.V.I. AND EKUNDAYO, J.A. 1978. Faecal Pollution of the Lagos Lagoon. Nigerian Journal of Sciencce, 12,39-53.

AMUND, O.O., IGIRI, C.O. 1990. Biodegradation of petroleum hydrocarbons under tropical estuarine conditions. World Journal of Microbiology and Biotechnology, 6, 255-262.http://dx.doi.org/10.1007/bf01201293

ANTONGIOVANN, M.I., SARGENTINI, C. 1991.Variability in the chemical composition of straws. Options Mediterraneennes, 16, 49-53.

BALL, A.S., BETTS, W.B., MCCARTHY, A.J. 1989. Degradation of lignin related compounds by Actinomycetes. Applied Environmental Microbiology, 55 , 1642-1644.

BOUVENG, H.O. AND SOLYMON, P. 1973. Long term stability of waste lignins in aquatic systems. Svendsk. Papperstidin, 76, 26-29.

BURAIMOH, O.M., ILORI M.O., AMUND, O. O. MICHEL, F.C., GREWAL S. K. 2015b. Assessment of bacterial degradation of lignocellulosic residues (sawdust) in a tropical estuarine microcosm using improvised floating raft equipment. International Biodeterioration and Biodegradation 104,186-193. http://dx.doi.org/10.1016/j.ibiod.2015.06.010

BURAIMOH, O.M., ILORI, M.O., AMUND, O.O. 2015a. Characterization of lignocellulolytic bacterial strains associated with decomposing wood residues in the Lagos lagoon, Nigeria. Malaysian Journal of Microbiology 11(3), 273-283.

CHANDRA, R., SINGH, S., REDDY, M.M.K., PATEL, D.K., PUROHIT, H.J.,

KAPLEY, A. 2008. Isolation and characterization of bacterial strains Paenibacillus sp. and Bacillus sp. for kraft lignin decolorization from pulp paper mill waste. Journal of General and Applied Microbiology 54, 399-407. http://dx.doi.org/10.2323/jgam.54.399

CHANDRA, R., RAJ, A, PUROHIT, H.J., KAPLEY, A. 2007. Characterization and optimization of three potential aerobic bacterial strains for kraft lignin degradation from pulp paper waste. Chemosphere 67(4),839-846 http://dx.doi.org/10.1016/j.chemosphere.2006.10.011 CHANDRA， R.,SINGH, R., YADAF, S. 2011. Effect of bacterial inoculum ratio in mixed culture for decolorization and detoxification of pulp paper mill effluent. Journal of Chemical Technology and Biotechnology, 87, 436-444. http://dx.doi.org/10.1002/jctb.2758 CHANDRA, R., SINGH, R., 2012. Decolourisation and detoxification of rayon grade pulp paper mill effluent by mixed bacterial culture isolated from pulp paper mill effluent polluted site. Biochemical Engineering Journal, 61, 49-58. http://dx.doi.org/10.1016/j.bej.2011.12.004

CHEN, F., DIXION, R.A. 2007. Lignin modification improves fermentable sugar yields for biofuel production. Nature Biotechnology, 25, 759-761. http://dx.doi.org/10.1038/nbt1316.
CHUPHAL, Y., KUMAR, V., THAKUR, I.S. 2005. Biodegradation and decolorization of pulp and paper mill effluent by anaerobic and aerobic microorganisms in a sequential bioreactor. World Journal of Microbiology and Biotechnology, 21,1439-1445 http://dx.doi.org/10.1007/s11274-005-6562-5 CRAWFORD, D. L., CRAWFORD, R. L. 1980. Microbial degradation of lignin. Enzyme and Microbial Technology, 2 (1),11-22. http://dx.doi.org/10.1016/0141 0229(80)90003-4

DEHORTER, B., BLONDEAU, R. 1992. Extracellular enzyme activities during humic acid degradation by the white rot fungi Phanerochaete chrysosporium and Trametes versicolor. FEMS Microbiology Letters, 94, 209-216. http://dx.doi.org/10.1016/0378-1097(92)90632-x

DESCHAMPS, A.M., MAHOUDEAU, G., LEBEAULT, J.M. 1980. Fas degradation of kraft lignin by Bacteria. European Journal of Applied Microbiology and Biotechnology, 9, 45-51. http://dx.doi.org/10.1007/bf00500001 EL-HANAFY, A.A., ABD-ELSALAM, H. E., HAFEZ, E. E. 2008. Molecular characterization of two native Egyptian lignolytic bacterial strains. Journal of Applied Science Resource, 4 (10), 1291-1296.

FROLUND, B, PALMGREN, R., KEIDING, K. ,NIELSEN, P.H. 1996 Extraction of extracellular polymers from activated sludge using a cation exchange resin. Water Resource,30 (8), $1749 \quad$ - 1758 http://dx.doi.org/10.1016/0043-1354(95)00323-1

HASSAN, E. A., AMR, A. E. 2009. Lignin biodegradation with ligninolytic bacterial strain and comparison of Bacillus subtilis and Bacillus $\mathrm{sp}$. isolated from Egyptian soil. Journal of Agriculture and Environmental Science, 5(1), 39-44 HERNANDEZ, M., HERNANDEZ-CORONADO, M.J., MONTIEL, M.D., RODRIGUEZ, J. ARIAS, M.E. 2001. Analysis of alkali-lignin in a paper mill effluent decolourised with two Streptomyces strains by gas chromatography AMass spectophotometry after cupric oxide degradation. Journal of Chromatography, 919(2), 389-394. http://dx.doi.org/10.1016/s00219673(01)00813-5

KIRBY, R., 2005. Actinomycetes and lignin degradation. Advances in Applied Microbiology 58; 125 -164. http://dx.doi.org/10.1016/s0065-2164(05)58004-3 KIZHAKKEDATHU, N. N., RAJEEV, K..S., PARUKUTTYAMMA PREMA, 2007. Utilization of rice straw for laccase production by Streptomyces psammoticus in solid-state fermentation. Journal of Industrial Microbiology and Biotechnology, 34, 665-674. http://dx.doi.org/10.1007/s10295-007-0239-z

KIZHEKKEDATHU, N.N., PARUKUTTYYAMMA, P. 2005. Mangrove Actinomycetes as the source of lignolytic Enzymes. Actinomycetologica , 19, 4047. http://dx.doi.org/10.3209/saj.19.40

MACHCZYNSKI, M. C., VIJGENBOOM, E, SAMYN, B., CANTERS, G. W. 2004. Characterization of SLAC: A small laccase from Streptomyces coelicolor with unprecedented activity. Protein Science, 13,2388-2397. http://dx.doi.org/10.1110/ps.04759104

MARTON, J. 1971. Reactions in alkaline pulping: lignins: occurrence, formation, Structure and reactions. K.V.Sarkanen and C.H. Ludwig : Eds Wiley \& Sons, N.Y.916 p.

MASAI, E., KATAYAMA, Y., FUKUDA, M. 2007. Genetic and biochemical investigations of bacterial catabolic pathways for lignin-derived aromatic compounds. Bioscience, Biotechnology and Biochemistry 71, 1-15. http://dx.doi.org/10.1271/bbb.60437.

MONTIES, B., ODIER, E., JANIN, G., CZANINSKI, Y.1981. Ultrastructura Evidence of Bacterial and Chemical Delignification of Poplar Wood. Holzforschung, 35(5), 217 - 222. http://dx.doi.org/10.1515/hfsg.1981.35.5.217

MORII, H., NAKAMIYA, K., KINOSHITA, S. 1995. Isolation of lignin decolourising bacterium. Journal of Fermentation and Bioengineering 80, 296 299. http://dx.doi.org/10.1016/0922-338x(95)90835-n

PERESTELO, F, FALCON, M.A., PEREZ, M.L., ROIG, E.C., MARTIN, G.D.L.F. 1989. Bioalteration of kraft pine lignin by Bacillus megaterium isolated from compost piles. Journal of Fermentation and Bioengineering, 68,151-153. http://dx.doi.org/10.1016/0922-338x(89)90066-4

POMETTO III, A.L., CRAWFORD, D. L. 1986. Effect of $\mathrm{pH}$ on lignin and cellulose degradation by Streptomyces viridosporus. Applied and Environmental Microbiology, 52(2), 246-250.

RAJ, A., REDDY, M.M.K., CHANDRA, R., PUROHIT, H.J., KAPLEY, A 2007. Biodegradation of kraft-lignin by Bacillus sp. isolated from sludge of pulp $\begin{array}{llllll}\text { and paper mill. Biodegradation, } 18 & (6), & 783 & -792\end{array}$ http://dx.doi.org/10.1007/s10532-007-9107-9

SRIDEVI, B., SINGARACHARYA, M. A. 2011. Isolation, identification and screening of potential cellulase-free xylanase producing fungi. African Journal of Biotechnology, 10, 4624-4630.

TIEN, M., KIRK, T.K. 1983. Lignin-degrading enzymes from hymenomycete

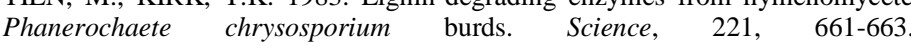
http://dx.doi.org/10.1126/science.221.4611.661

TOMATI, U., GALLI, E., PASETTI, L.,VOLTERRA, E. 1995. Bioremediation of olive-mill waste water by composting. Waste Management and Research 13(6), 509-518. http://dx.doi.org/10.1177/0734242x9501300602

WONG, D.W.S. 2008. Structure and action mechanism of lignolytic enzymes. Applied Biochemistry and Biotechnology,157, 174-209. http://dx.doi.org/10.1007/s12010-008-8279-z 
YAN, S., LIYUAN, C., CHONGJIAN, T., ZHIHUI, Y., YU, Z., YUEHUI, C.,

QINGXIU, J. 2013. Biochemical investigation of kraft lignin degradation by

Pandoraea sp. B-6 isolated from bamboo slips. Bioprocess and Biosystems

Engineering. 36(12): 1957-1965. http://dx.doi.org/10.1007/s00449-013-0972-9 